This is the author's final, peer-reviewed manuscript as accepted for publication. The publisher-formatted version may be available through the publisher's web site or your institution's library.

\title{
Food Safety Practices Lacking in Independent Ethnic Restaurants
}

Kevin R. Roberts, Junehee Kwon, Carol W. Shanklin, Pei Liu, Wen-Shen Yen

\section{How to cite this manuscript (APA format)}

If you make reference to this version of the manuscript, use the following citation format:

Roberts, K., Kwon, J., Shanklin, C., Liu, P., Yen, W. (2011). Food Safety Practices Lacking in Independent Ethnic Restaurants. Retrieved from http://krex.ksu.edu

\section{Published Version Information}

Citation: Roberts, K., Kwon, J., Shanklin, C., Liu, P., Yen, W. (2011). Food Safety Practices Lacking in Independent Ethnic Restaurants. Journal of Culinary Science \& Technology. 9(1)1- 16.

Copyright: Copyright @ T Taylor \& Francis Group

Digital Object Identifier (DOI): DOI: 10.1080/15428052.2011.549041

Publisher's Link: http://www.informaworld.com/openurl?genre=article\&issn=1542$8052 \&$ volume $=9 \&$ issue $=1 \&$ spage $=1$

This item was retrieved from the K-State Research Exchange (K-REx), the institutional repository of Kansas State University. K-REx is available at http://krex.ksu.edu 
4

*Corresponding Author

\author{
Kevin R. Roberts, PhD* \\ Assistant Professor \\ Department of Hospitality Management and Dietetics \\ Kansas State University \\ Manhattan, KS \\ 785.532 .2399 \\ kevrob@ksu.edu \\ Junehee Kwon, PhD, RD \\ Associate Professor \\ Department of Hospitality Management and Dietetics \\ Kansas State University \\ Manhattan, KS
}

\title{
Carol W. Shanklin, PhD, RD
}

Dean and Professor

KSU Graduate School

Kansas State University

Manhattan, KS

\section{Pei Liu}

Graduate Research Assistant

Department of Hospitality Management and Dietetics

Kansas State University

Manhattan, KS

\section{Wen-Shen Yen}

Graduate Research Assistant

Department of Hospitality Management and Dietetics

Kansas State University

Manhattan, KS

Running Head: Food Safety in Ethnic Restaurants 
3 Abstract

4

11 categories. Overall, non-ethnic restaurants had higher food code compliance scores than

12 independent and chain ethnic restaurants.

\section{Food Safety Practices Lacking in Independent Ethnic Restaurants}

275 individual Kansas Food Code violations and the number of critical and non-critical

0 code violations were found between independent ethnic restaurants and the other three restaurants and identified specific food safety practices needing improvement. Frequencies for

7 violations were compared between independent ethnic, chain ethnic, independent non-ethnic, and

8 chain non-ethnic restaurants. Independent ethnic restaurants had significantly more critical and

9 non-critical violations than the other three types of restaurants. The majority of differences in

13

14

15 


\section{Food Safety Practices Lacking in Independent Ethnic Restaurants}

3

The National Restaurant Association (NRA) projected that the restaurant industry will serve more than 70 billion meals or snack occasions in 2009 and will garner $48 \%$ of the consumer food dollar (NRA, 2009a). The restaurant industry continues to be a pillar in the American economy and plays a significant role in the fast-paced lives of American consumers who demand convenience in all aspects of their lives, including the food they eat and prepare for their family. In fact, $45 \%$ of Americans indicate that restaurant operations play a pivotal role in their lives. In 2009, restaurant industry sales are expected to exceed $\$ 566$ billion (NRA, 2008). Research has shown that $53 \%$ of consumers eat outside the home at least once per week, $17 \%$ dine outside the home on average of five or more times per week (Jones, Vugia, Selman, Angulo, and EIP FoodNet Working Group, 2002), and 4\% dine outside the home seven or more times in any given week (Garman et al., 2002). Given the increasing number of Americans that dine in a restaurant or other foodservice operation on a daily basis, food safety practices in restaurants are critical to protecting the health of the American public.

Restaurant owners and managers depend on frontline employees on a daily basis to prepare and serve safe food to customers. Restaurant operations have been reported to be the cause of between 52\% (Jones \& Angulo, 2006) and 59\% (Centers for Disease Control and Prevention, 2006) of foodborne illness outbreaks in the United States. Foodservice employees play a pivotal role in the prevention of foodborne disease (Harrington, 1992).

In 1998, the Food and Drug Administration (FDA) began to collect baseline data of food safety practices in foodservice operations. The first report, the Report of the FDA Retail Food Program Database of Foodborne Illness Risk Factors, was released in 2000 and focused on and 
explored major risk factors that are attributed to foodborne disease (FDA Retail Food Program

2 Steering Committee, 2000). The report indicated that full service restaurants were $40 \%$ out-of-

3 compliance with overall food code standards. Fast food restaurants were slightly better with an

4 overall out-of-compliance rate of $26 \%$. These out-of-compliance rates are higher than other non-

5 commercial foodservice establishments such as hospitals, nursing homes, and elementary

6 schools. In full service restaurants, the most often out-of-compliance practices included cooling

7 potentially hazardous foods to $70^{\circ} \mathrm{F}$ within two hours $(85 \%)$, proper adequate handwashing

$8(81 \%)$, and holding potentially hazardous foods at $41^{\circ} \mathrm{F}$ or below $(81 \%)$. The report identified

915 practices that were in need of "priority attention," the most of any operation. The most out-

10 of-compliance practices in fast food restaurants included ready-to-eat, potentially hazardous

11 foods date marked after 24 hours (71\%), holding potentially hazardous foods at $41^{\circ} \mathrm{F}$ or below

$12(62 \%)$, and prevention of hand contamination (58\%) (FDA Retail Food Program Steering

13 Committee, 2000). All of the top practices that are out-of-compliance in both fast food and full

14 service restaurants are directly related to employee food safety knowledge and on-the-job

15 practices of foodservice employees.

16 In 2003, the FDA began collecting data to follow-up on the initial report. The report,

17 published in 2004 showed only marginal overall improvement, with $38.5 \%$ and $25 \%$ out-of-

18 compliance rates for full service and fast food restaurants, respectively. Because of the relatively

19 high incidence that restaurants are out-of-compliance with risk factors, food safety should be of

20 utmost concern to restaurant owners/managers. The 2004 report showed that the practices most

21 often out-of-compliance in full service restaurants included holding potentially hazardous foods

22 at $41^{\circ} \mathrm{F}$ or below $(77.8 \%)$, cooling potentially hazardous foods to $70^{\circ} \mathrm{F}$ within two hours

23 (77.3\%), and potentially hazardous foods date marked after 24 hours (74.2\%). The most out-of- 
1

2

compliance practices in fast food restaurants included date marking of commercially processed ready-to-eat foods $(57.6 \%)$, ready-to-eat, holding potentially hazardous foods at $41^{\circ} \mathrm{F}$ or below (56.5\%), and potentially hazardous foods date marked after 24 hours (40.7\%) (FDA National Retail Food Team, 2004).

Many studies have shown that there are critical practices in restaurants that are simply not being followed. For example, Roberts and Sneed (2003) surveyed independent restaurant managers in Iowa and found that $43.2 \%$ of respondents did not have specifications for cleaning and sanitizing equipment, $24 \%$ did not have a policy on handwashing, and $46 \%$ did not have basic procedures in place to check the temperatures of food upon receiving. However, when sanitarians in Kansas and Iowa were asked the same questions and asked to estimate the number of operations they inspected that had food safety programs in place, their responses were drastically lower. Of those sanitarians who responded, $80 \%$ indicated independent restaurants did not have specifications for cleaning and sanitizing equipment, $82 \%$ did not have a policy on handwashing, and $90 \%$ did not have basic procedures in place to check the temperatures of food upon receiving. In this study, chain restaurant operations performed better with sanitarians estimating that only $37 \%$ of chain restaurants did not have specifications for cleaning and sanitizing equipment, $6 \%$ did not have a policy on handwashing, and $47 \%$ did not have basic procedures in place to check the temperatures of food upon receiving (Roberts, Barrett, \& Sneed, 2005).

While research has been conducted to explore food safety practices in fast food and full service restaurants and independent and chain restaurants, there is a paucity of research that has explored food safety practices in ethnic restaurants when compared to their non-ethnic counterparts. As the ethnic population of the United States continues to increase, so do demands 
1 for authentic ethnic foods as Americans are introduced to food from around the globe (Hensley \&

2 Bohm, 2000a; Hensley \& Bohm, 2000b; Howell, 2005). Over half of Americans surveyed

3 indicated that they eat ethnic foods frequently, and 90\% indicated that they are familiar with these

4 types of food offerings (Hensley \& Bohm, 2000a). One of the major trends in the restaurant

5 industry is the increasing number of ethnic restaurants. During the past 10 years, Italian, Mexican,

6 and Chinese cuisines have become so popular that they are now considered mainstream in

7 American culture (Hensley \& Bohm, 2000a). This should come as no surprise as the diversity in

8 ethnic cultures in the United States continues to increase. By 2042, the minority population in the

9 United States is expected to become the majority, with nearly one third of all U.S. residents being

10 of Hispanic heritage (Bernstein \& Edwards, 2006). Of the ethnic population, Asians and

11 Hispanics are the two largest minority groups who own restaurant operations, with $15 \%$ of

12 restaurants owned by Asians and 8\% by Hispanics (NRA, 2009b).

13 Between 1990 and 2000, the total number of foodborne disease outbreaks traced back to

14 ethnic foods increased 7\%, with the most outbreaks being reported for Mexican, Italian, or Asian

15 foods. Of these, $43 \%$ were attributed to food served in a restaurant (Simonne, Nelle, Evans, \&

16 Marshall, 2004).

Mauer et al. (2006) found that improper food temperatures, cross-contamination, and

18 employee hygiene were among the top concerns for food safety professionals when dealing with

19 ethnic restaurant operations. Respondents in this survey cited language barriers as a major

20 concern. Language has also been found as a barrier in other food safety related studies

21 (Bermúdez-Millán, Pérez-Escamilla, Damio, González, Segura-Pérez, 2004; Rudder, 2006).

22 Rudder (2006) concluded that operators of ethnic restaurants were willing to learn proper

23 food safety practices in order to operate within the law; however, operators did not initially 
1 comprehend the importance of following proper food safety practices and the relevance to their establishment. Simonne et al., (2004) posited that "current food manager certification may not adequately cover specific details essential for safe ethnic food preparation" (Simonne et al. 2004,

4 590). Therefore, the purpose of this study was to compare compliance with the Food Code

5 between ethnic and non-ethnic restaurants. Specific objectives were to:

6

\section{Methodology}

\section{Sample} restaurants.
1. Determine if critical and non-critical violations differ based on ownership of the operation (e.g., independent ethnic restaurant, chain ethnic restaurant, independent non-ethnic restaurant, chain non-ethnic restaurant).

2. Determine which health code violations are more prevalent in ethnic versus nonethnic restaurants.

3. Identify specific food safety practices needing improvement in ethnic restaurants. chosen from 14 Kansas counties with the highest populations of Asians and Hispanics in the state. A listing of operations licensed to sell food in the state of Kansas was obtained from the state agency responsible for inspections. Operations not classified as a commercial restaurant were excluded from the sample. This included non-commercial foodservice operations, such as schools and nursing homes, and establishments that do not provide food as the main product such as gas stations and bars. The listing was then subdivided into four groups: independent nonethnic restaurants, chain non-ethnic restaurants, independent ethnic restaurants, and chain ethnic 
Two-hundred and fifty restaurants in each of the four different classifications were

2

3

4

chosen for the sample. Independent non-ethnic restaurants $(\mathrm{n}=250)$, chain non-ethnic restaurants $(\mathrm{n}=250)$, and independent ethnic restaurants $(\mathrm{n}=250)$ were selected utilizing a stratified random sample. Because there were only 174 chain ethnic restaurants available in the identified counties, all chain ethnic restaurants were included in the study. The total number of establishments was 924 .

\section{Data Collection}

Once the sample was determined, health inspection reports were gathered from the online Kansas Health Inspection Database (Kansas Department of Health and Environment, 2008). For each operation, the inspection report with the highest number of total (both critical and noncritical) violations from September 1, 2007 through August 31, 2008 was utilized for data analysis. Since this information is considered public records and no human subjects were involved in the research protocol, the approval of the institutional review board was not needed.

Data was gathered for each inspection item in the Kansas Food Code, and included 275 different inspection criteria (Kansas Department of Agriculture, 2005). Violations were recorded based on the number of times it was noted on the operation's inspection report. For the majority of inspections, specific violations within each operation were noted only once on the inspection report. Others, for example, "effective pest control measures in place; dead or trapped pest removed from traps at adequate frequency" were noted multiple times in the same operation during the inspection and thus were recorded with the total number of times it was noted on the inspection report.

Two research assistants entered health inspection data into the data collection form then into a Microsoft Access Database. To validate the classification of the ethic restaurants, 
1 researchers utilized phonebooks, restaurant websites, or telephone calls to the operation. After

2 the initial data entry was complete, the data was cross checked to ensure accuracy and then

3 converted to SPSS, Version 15.0 for analysis. Descriptive statistics computed included

4 frequencies, means, and standard deviations. Analysis of variance with Scheffe's post hoc

5 analysis was used to compare the total number of critical and non-critical violations overall and

6 between each of the different cohorts within the sample (chain non-ethnic restaurants,

7 independent ethnic restaurants, chain ethic restaurants, and independent non-ethnic restaurants).

8 Results

9 The final sample included independent ethnic restaurants $(\mathrm{n}=250)$, chain non-ethnic

10 restaurants $(\mathrm{n}=250)$, independent ethnic restaurants $(\mathrm{n}=250)$, and chain ethnic restaurants

$11(\mathrm{n}=174)$. There were 14 different types of ethnic cuisine represented in the sample (Table 1).

12 Within the sample of ethnic restaurants $(\mathrm{n}=424)$, the majority of ethnic restaurants were Mexican $13 \quad(54.7 \%)$ or Chinese (24.1\%).

\section{INSERT TABLE 1}

Overall, the average number of critical and non-critical violations and number of inspections per year were $3.23 \pm 2.73,1.87 \pm 2.19$, and $1.95 \pm 1.31$, respectively. An analysis of variance (ANOVA) with Scheffe's post hoc test was used to explore differences in the total

21 numbers of critical and non-critical violations and number of inspections among the four types of

22 restaurants: independent ethnic restaurants, independent non-ethnic restaurants, chain ethnic

23 restaurants, and chain non-ethnic restaurants. Independent ethnic restaurants had significantly 
1 more violations and inspections than independent non-ethnic restaurants, chain non-ethnic

2 restaurants, and chain ethnic restaurants $(p<0.001)$ (Table 2). Independent ethnic restaurants

3 had more inspections than any of the other categories of restaurants $(p<0.001)$. However, no

4 differences in the number of inspections were noted between independent and chain non-ethnic 5 restaurants.

6

7

8

9

10

11

12 and chain operations. In 38 of the 275 individual violations explored, significant differences at a

13 type I error rate of .05 was noted (Table 3). In most cases, specific differences were found

14 between independent ethnic restaurants and the other three categories. There were no violations

15 where non-ethnic restaurants, neither chain nor independent, had significantly higher mean

16

17 items where differences in mean scores did exist are considered a critical violation per the

18 Kansas food code and these items are likely to contribute to a foodborne illness.

\section{Discussion and Conclusions}

INSERT TABLE 3 
Results reveal that proper food safety practices are implemented less frequently in

2 independent ethnic restaurants as evidenced by the number of food code violations when

3 compared to chain ethnic and independent and chain non-ethnic restaurants. The expected

4 increase in ethnic foodservice operations in the United States (Howell, 2005) brings to the

5 forefront the importance of ensuring safe food is served to the customer. Results show that food

6 safety training programs and interventions geared towards ethnic independent restaurant

7 operators are needed. Programs must help ethnic restaurant employees and operators understand

8 the importance of proper food safety practices within the operation. Moreover, helping ethnic

9 foodservice managers and operators who might be first-generation immigrants understand food

10 safety laws and codes within the United States is paramount. Straight forward guides about food

11 safety codes and proper practices should be made available in the operators' native language to

12 assist them in understanding the laws and food code. Operational manuals and signage must also

13 be available in the native language of the foodservice manager or owner in order to allow for

14 effective training of food production employees in the ethnic restaurant environment.

Chain ethnic restaurants did not differ in the number of critical and non-critical violations

16 when compared to chain and independent non-ethnic restaurants. While this study did not

17 explore why this is the case, it is posited that chain operations have the support and resources of

18 a corporate office, while the independent ethnic operations do not. Further, chain restaurant

19 operations often have stringent internal controls that are sometimes stricter than actual health

20 code regulations. A language barrier or lack of understanding the food code by the owner,

21 manager, and employees may prevent independent ethnic operations from performing better on

22 inspections. The chain ethnic operations would likely have more support from the corporate

23 office in terms of translating, educating, and policy-making related to the food code. 
Independent ethnic restaurants had a greater frequency of health inspections than chain

2

ethnic and non-ethnic restaurants. These results signal a potential problem within independent ethnic restaurant operations. In Kansas, as in most states, restaurant operations are inspected once per year. After the initial yearly inspection, subsequent inspections could be needed for follow-up of major issues that need to be corrected. Other inspections can occur based on complaints from customers and employees, or if an operation is suspected of contributing to a foodborne illness outbreak. Therefore, the greater the number of inspections in a given operation, the more it signals the potential of food safety problems within the facility. A number of the inspection items where violations occurred are directly related to employee food safety practices. Time and temperature abuse, personal hygiene, and crosscontamination have routinely been identified as the most common contributors of foodborne illness (FDA National Retail Food Team, 2004; FDA Retail Food Program Steering Committee, 2000) and are directly related to employee food safety practices. Managers must assure that employees are knowledgeable about proper food safety practices and that they follow these practices while on-the-job. It only takes one employee who does not follow proper food safety practices to cause a wide spread foodborne illness outbreak in any foodservice facility. Managers and operators of ethnic foodservice operations must also be aware of code requirements. Several of the inspection items found to be significantly different between ethnic and non-ethnic foodservice operations are related to faculty maintenance and design. For example, ensuring that the operation is protected against the entry of pests is a critical violation and was found to be a significant issue in ethnic restaurant operations. Even if all employees followed proper food safety practices, they will be unable to prepare safe food if it has been contaminated by pests. 
The findings from this study indicate that independent ethnic foodservice operations

2 have specific practices that need to be addressed. Findings about the difference between ethnic

3 and non-ethnic foodservice operations indicate that further research is needed to explore food

4 safety training and behaviors in ethnic restaurants. These findings are significant for operators,

5 health inspectors, and food safety educators. While the types of violations found are similar to

6 those found in the Food and Drug Administration studies (FDA National Retail Food Team,

7 2004; FDA Retail Food Program Steering Committee, 2000), this study points to specific

8 practices in ethnic restaurants that are problematic and need to be addressed. Further research is

9 also warranted that explores the differences within specific types of ethnic restaurants. This

10 study was unable to test for differences among the different types of ethnic cuisines (Asian,

11 Mexican, Irish, etc) due to a limited sample size within some of the categories.

Future studies in ethnic restaurant and with ethnic employees are needed to explore

13 ethnic employees' level of knowledge relative to U.S. food safety requirements. First and

14 second generation immigrants may not understand sanitation procedures in the United States and

15 may be accustomed to far less concern among the general public over food safety in their home

16 countries when compared to the United States. In-depth research is needed to explore the

17 barriers that prevent ethnic owners, operators, and employees from following proper practices as

18 outlined in the food code. Knowledge issues are fairly easy to overcome with current food safety

19 training programs that are available, such as ServSafe, sponsored by the NRA Educational

20 Foundation. However, ServSafe has been found to not address issues that impact behavior, such

21 as attitudes, subjective norms, or perceptions of control (Roberts et al., 2008; York et al., 2009).

22 Therefore, future research is warranted that explores not only the knowledge component, but the

23 antecedents of actual behavior. 
2 operation. Therefore, results can only be generalized to ethnic restaurants and not the ethnicity

3 of the owner. It is plausible that many ethnic owners/managers exist within independent and

4 chain non-ethnic restaurants and ethnic restaurants can be owned/managed by non-ethnic

5 individuals. Further research could explore the ethnic background of the owner and the role it

6 plays in overall food safety programs within restaurant operations.

8 generalized beyond Kansas. The results of this study included data gathered for restaurant

9 operations only. Thus, results cannot be generalized to other types of foodservice systems. 


\section{References}

3

Bernstein, R., \& Edwards, T. (2008). An Older and More Diverse Nation by Midcentury. U.S. Census Bureau. Retrieved May 17,2009 from: http://www.census.gov/PressRelease/www/ releases/archives/population/012496.html

Bermúdez-Millán, A., Pérez-Escamilla, R., Damio, G., González A., Segura-Pérez, S. (2004). Food safety knowledge, attitudes, and behaviors among Puerto Rican caretakers living in Hartford, Connecticut. Journal of Food Protection, 67(3), 512-516.

Center for Disease Control and Prevention. (2006). Preliminary FoodNet Data on the Incidence of Infection with Pathogens Transmitted Commonly Through Food: 10 States, United States, 2005 [Electronic version]. Morbidity and Mortality Weekly Report, 55(14), 392-395.

FDA National Retail Food Team. (2004). FDA Report on the Occurrence of Foodborne Illness Risk Factors in Selected Institutional Foodservice, Restaurant, and Retail Food Store Facility Types. Washington, D.C.: U.S. Food and Drug Administration. Accessed November 3, 2009 from: http://www.fda.gov/Food/FoodSafety/RetailFoodProtection/ FoodborneIllnessandRiskFactorReduction/RetailFoodRiskFactorStudies/ucm089696.htm

FDA Retail Food Program Steering Committee. (2000). Report of the FDA Retail Food Program Database of Foodborne Illness Risk Factors Washington, D.C. Accessed November 3, 2009 from: http://www.fda.gov/downloads/Food/FoodSafety/RetailFoodProtection/ FoodborneIllnessandRiskFactorReduction/RetailFoodRiskFactorStudies/ucm123546.pdf

Garman, R., Vugia, D., Marcus, R., Segler, S., Hawkins, M., Bogard, A., Anderson, B., Jones, T., \& EIP FoodNet Working Group. (2002). Restaurant-associated Behavior from the FoodNet Population Survey, 1998-99. Proceedings from the International Conference on Emerging Infectious Diseases. Atlanta, GA.

Harrington, R. E. (1992). The role of employees in the spread of foodborne disease-food industry views of the problem and coping strategies. Dairy, Food and Environmental Sanitation, 12, 62-63.

Hensley, S., \& Bohm, E., (2000a). International Cuisine Reaches America's Main Street. Accessed May 29, 2009 from: http:/www.restaurant.org/pressroom/pressrelease.cfm?ID= 124

Hensley, S., \& Bohm, E., (2000b).Non-Traditional Ethnic Cuisines Gain in Popularity. Accessed May 29, 2009 from: http:/www.restaurant.org/pressroom/pressrelease.cfm?ID= 126

Howell, D. (2005). Retailers must keep pace with evolving palates. Accessed June 7, 2009 from: $\mathrm{http} / / /$ findarticles.com/p/articles/mi_m0FNP/is_14_44/ai_n14868156/ 
Jones, T., Vugia, D., Selman, C., Angulo, F., \& EIP FoodNet Working Group. (2002). Eating in Restaurants: A Risk Factor for Foodborne Illness? Findings from FoodNet to Be Explored by EHS-Net. Proceedings from the International Conference on Emerging Infectious Diseases. Atlanta, GA

Jones, T. F., \& Angulo, F. J. (2006). Eating in Restaurants: A Risk Factor for Foodbrone Disease? Clinical Infectious Diseases, 43(10), 1324-1328.

Kansas Department of Health and Environment. (2008). Bureau of Consumer Health: Food Service Inspections. Accessed February, 29, 2009 from: http://kensas.kdhe.state.ks.us/pls/ certop/fssearch

Kansas Department of Agriculture. (2005). Kansas Food Code 2005. Accessed August 11, 2009 from: http://www.ksda.gov/includes/statute_regulations/food_safety/KS_Food_Code05_11_ 24_08.pdf

Mauer, W. A, Kaneene, J. B., DeArman, V. T., Roberts, C. A., Miller, A., Pong, L., \& Dickey, T. E. (2006). Ethnic-Food Safety Concerns: An Online Survey of Food Safety Professionals. Journal of Environmental Health, 68(10), 32-38.

National Restaurant Association. (2008). 2009 Restaurant Industry Forecast. Washington, D.C.: National Restaurant Association.

National Restaurant Association. (2009a). 2009 Restaurant Industry Pocket Factbook. Washington, D.C.: National Restaurant Association. Accessed May 29, 2009 from: http://www.restaurant.org/pdfs/research/2009Factbook.pdf

National Restaurant Association. (2009b). Restaurant Industry -- Facts at a Glance. Washington, D.C.: National Restaurant Association. Accessed September 10, 2009 from http://www.restaurant.org/research/ind_glance.cfm

Roberts, K. R., Barrett, B. B., Howells, A. D., Shankling, C. W., Pilling, V. K., \& Brannon, L. A. (2008). Food Safety training and foodservice employees knowledge and behavior. Food Protection Trends, 28(4), 252-260.

Roberts, K. R., Barrett, B., \& Sneed, J. (2005). Status of prerequisite and HACCP program implementation in Iowa and Kansas restaurants: Sanitarians' perspective. Food Protection Trends, 25(9), 694-700.

Roberts, K. R., \& Sneed, J. (2003). Status of Prerequisite and HACCP Program implementation in Iowa restaurants. Food Protection Trends, 23(10), 808-816.

Rudder, A. (2006). Food safety and the risk assessment of ethnic minority food retail businesses. Food Control, 17(3), 189-196. 
1 Simonne, A. H., Nille, A., Evans, K., \& Marshall, Jr, M. R. (2004). Ethnic Food Safety Trends in 2 the United States Based on CDC Foodborne Illness Data. Food Protection Trends, 24(8), 3 590-604.

4 York, V. K., Brannon, L. A., Shanklin, C. W., Roberts, K. R., Howells, A. D., Barrett, E. B. 5 (2009). Foodservice employees benefit from interventions targeting barriers to food safety. 6 Journal of the American Dietetic Association, 109, 1576-1581. 
Table 1. Types of Ethnic Restaurants in the Sample $(\mathrm{N}=424)$

\begin{tabular}{|c|c|c|c|c|c|c|}
\hline \multirow[b]{2}{*}{ Characteristic } & \multicolumn{2}{|c|}{$\begin{array}{c}\text { Independent } \\
\text { Ethnic }\end{array}$} & \multicolumn{2}{|c|}{ Chain Ethnic } & \multicolumn{2}{|c|}{ Total } \\
\hline & $\mathbf{n}$ & $\%$ & $\mathbf{n}$ & $\%$ & $\mathbf{n}$ & $\%^{\mathrm{a}}$ \\
\hline Ethnicity & & & & & & \\
\hline Mexican & 106 & 25.0 & 126 & 29.7 & 232 & 54.7 \\
\hline Chinese & 68 & 16.0 & 34 & 8.0 & 102 & 24.0 \\
\hline Italian & 9 & 2.1 & 14 & 3.3 & 23 & 5.4 \\
\hline Japanese & 22 & 5.2 & -- & -- & 22 & 5.2 \\
\hline Thailand & 13 & 3.1 & -- & -- & 13 & 3.1 \\
\hline Other & 10 & 2.4 & -- & -- & 10 & 2.4 \\
\hline Vietnamese & 6 & 1.4 & -- & -- & 6 & 1.4 \\
\hline Indian & 5 & 1.2 & -- & -- & 5 & 1.2 \\
\hline French & 3 & 0.7 & -- & -- & 3 & 0.7 \\
\hline Korean & 3 & 0.7 & -- & -- & 3 & 0.7 \\
\hline Greek & 2 & 0.4 & -- & -- & 2 & 0.4 \\
\hline Irish & 1 & 0.2 & -- & -- & 1 & 0.2 \\
\hline Malaysian & 1 & 0.2 & -- & -- & 1 & 0.2 \\
\hline German & 1 & 0.2 & -- & -- & 1 & 0.2 \\
\hline
\end{tabular}

${ }^{\mathrm{a}}$ Percentages may not equal $100 \%$ due to rounding errors.

Note: 500 non-ethnic restaurants (250 each independent and chain) were included in the sample for comparison purposes. 
Table 2. Mean Number of Critical and Non-critical Violations and Inspections Based on Restaurant Type

\begin{tabular}{|c|c|c|c|c|c|c|}
\hline \multirow[b]{2}{*}{ Dependent Variables } & $\begin{array}{l}\text { Independent } \\
\text { Ethnic } \\
\text { Operations } \\
(\mathbf{n}=\mathbf{2 5 0})\end{array}$ & $\begin{array}{c}\text { Chain } \\
\text { Ethnic } \\
\text { Operations } \\
(n=174)\end{array}$ & $\begin{array}{l}\text { Independent } \\
\text { Non-ethnic } \\
\text { Operations } \\
(n=250)\end{array}$ & $\begin{array}{c}\text { Chain } \\
\text { Non-ethnic } \\
\text { Operations } \\
(\mathbf{n}=\mathbf{2 5 0})\end{array}$ & \multirow[b]{2}{*}{$F$ value $^{\text {a }}$} & \multirow[b]{2}{*}{$P$ value } \\
\hline & \multicolumn{4}{|c|}{ Mean Number of Violations \pm SD } & & \\
\hline Number of Critical Violations & $4.52 \pm 2.97^{x}$ & $2.81 \pm 2.45^{\mathrm{y}}$ & $2.90 \pm 2.83^{\mathrm{y}}$ & $2.58 \pm 2.06^{\mathrm{y}}$ & 28.11 & $<0.001$ \\
\hline Number of Non-Critical Violations & $2.84 \pm 2.85^{\mathrm{x}}$ & $1.39 \pm 1.65^{\mathrm{y}}$ & $1.71 \pm 1.94^{\mathrm{y}}$ & $1.40 \pm 1.65^{\mathrm{y}}$ & 25.14 & $<0.001$ \\
\hline Number of Inspections & $2.29 \pm 1.63^{\mathrm{x}}$ & $1.88 \pm 1.13^{\mathrm{y}}$ & $1.76 \pm 1.11^{\mathrm{y}}$ & $1.85 \pm 1.18^{\mathrm{y}}$ & 8.25 & $<0.001$ \\
\hline
\end{tabular}


Table 3. Individual Inspection Items with Significant $(p \leq .05)$ differences Based on Type of Restaurant $(n=943)$

\begin{tabular}{|c|c|c|c|c|c|c|}
\hline \multirow[b]{2}{*}{ Description of Violation } & \multicolumn{4}{|c|}{ Mean \pm Standard Deviation } & \multirow[b]{2}{*}{$F$ value $^{\text {a }}$} & \multirow[b]{2}{*}{$P$ value } \\
\hline & $\begin{array}{l}\text { Independen } \\
\text { t Ethnic } \\
\text { Operations } \\
(n=250)\end{array}$ & $\begin{array}{c}\text { Chain } \\
\text { Ethnic } \\
\text { Operations } \\
(n=174) \\
\end{array}$ & $\begin{array}{l}\text { Independen } \\
\text { t Non- } \\
\text { ethnic } \\
\text { Operations } \\
(\mathrm{n}=\mathbf{2 5 0}) \\
\end{array}$ & $\begin{array}{c}\text { Chain } \\
\text { Non-ethnic } \\
\text { Operations } \\
(\mathbf{n}=\mathbf{2 5 0}) \\
\end{array}$ & & \\
\hline \multicolumn{7}{|l|}{ Demonstration of Knowledge } \\
\hline $\begin{array}{l}\text { PIC is able to demonstrate knowledge of foodborne disease prevention and } \\
\text { application of the Hazard Analysis and Critical Control Point.* }\end{array}$ & $.25 \pm .44^{\mathrm{w}}$ & $.11 \pm .31^{\mathrm{x}}$ & $.10 \pm .30^{\mathrm{x}}$ & $.07 \pm .26^{\mathrm{x}}$ & 14.37 & .000 \\
\hline \multicolumn{7}{|l|}{ Control of Hands as a Vehicle of Contamination } \\
\hline Employees use the correct handwashing procedure.* & $.09 \pm .29^{\mathrm{w}}$ & $.03 \pm .18^{\mathrm{x}}$ & $.04 \pm .06^{\mathrm{x}}$ & $.03 \pm .18^{\mathrm{x}}$ & 8.83 & .000 \\
\hline $\begin{array}{l}\text { Preventing contamination from hands, including minimizing bare hand } \\
\text { contact with ready-to-eat food.* }\end{array}$ & $.16 \pm .36^{\mathrm{w}}$ & $.07 \pm .25^{\mathrm{x}}$ & $.08 \pm .29^{\mathrm{x}}$ & $.06 \pm .24^{\mathrm{x}}$ & 5.49 & .001 \\
\hline Handwashing sinks must be accessible and not used for any other activity. & $.10 \pm .31$ & $.05 \pm .22$ & $.05 \pm .21$ & $.04 \pm .21$ & 2.84 & .037 \\
\hline Appropriate hand drying provisions available. & $.13 \pm .33^{\mathrm{w}}$ & $.06 \pm .24^{\mathrm{wX}}$ & $.11 \pm .32^{\mathrm{wX}}$ & $.04 \pm .21^{\mathrm{x}}$ & 4.73 & .003 \\
\hline \multicolumn{7}{|l|}{ Approved Sources } \\
\hline Food is obtained from approved sources.* & $.02 \pm .14$ & $.00 \pm .00$ & $.01 \pm .09$ & $.00 \pm .00$ & 2.81 & .039 \\
\hline \multicolumn{7}{|l|}{ Protection from Contamination } \\
\hline Separation of food items to prevent cross contamination.* & $.26 \pm .51^{\mathrm{w}}$ & $.12 \pm .41^{\mathrm{x}}$ & $.11 \pm .32^{\mathrm{x}}$ & $.02 \pm .14^{\mathrm{x}}$ & 17.46 & .000 \\
\hline $\begin{array}{l}\text { Contact surfaces and equipment must be sanitized before use and after } \\
\text { cleaning.* }\end{array}$ & $.15 \pm .36^{\mathrm{w}}$ & $.09 \pm .28^{\mathrm{wx}}$ & $.07 \pm .25^{\mathrm{x}}$ & $.07 \pm .26^{\mathrm{x}}$ & 4.46 & .004 \\
\hline \multicolumn{7}{|l|}{ Potentially Hazardous Food Time/Temperature } \\
\hline $\begin{array}{l}\text { Foods should be reheated so all parts reach an internal temperature of } 74 \\
\text { degrees } \mathrm{C} \text { for at least } 15 \text { seconds. }\end{array}$ & $.02 \pm .14^{\mathrm{wx}}$ & $.06 \pm .23^{\mathrm{w}}$ & $.02 \pm .14^{\mathrm{wx}}$ & $.01 \pm .09^{\mathrm{x}}$ & 3.86 & .009 \\
\hline $\begin{array}{l}\text { Cooked foods need to be cooled from } 57 \text { degrees } \mathrm{C} \text { to } 21 \text { degrees } \mathrm{C} \text { within } \\
2 \text { hours. Within a total of } 6 \text { hours from } 57 \text { degrees } \mathrm{C} \text { to } 5 \text { degrees C.* }\end{array}$ & $.13 \pm .35^{\mathrm{w}}$ & $.05 \pm .22^{\mathrm{x}}$ & $.06 \pm .23^{\mathrm{x}}$ & $.01 \pm .11^{\mathrm{x}}$ & 10.38 & .000 \\
\hline $\begin{array}{l}\text { Potentially hazardous foods must be maintained at appropriate temperature } \\
\text { of } 5 \text { degrees } \mathrm{C} \text { or less.* }\end{array}$ & $.56 \pm .69^{\mathrm{w}}$ & $.42 \pm .58^{\mathrm{wx}}$ & $.38 \pm .56^{\mathrm{x}}$ & $.36 \pm .57^{\mathrm{x}}$ & 5.22 & .001 \\
\hline $\begin{array}{l}\text { Food should be clearly marked to indicate the date food should be } \\
\text { consumed by, sold, or discarded.* }\end{array}$ & $.23 \pm .45^{\mathrm{w}}$ & $.07 \pm .25^{\mathrm{x}}$ & $.18 \pm .43^{\mathrm{wy}}$ & $.09 \pm .29^{x y}$ & 9.12 & .000 \\
\hline $\begin{array}{l}\text { Need written procedures to maintain food establishment or a maximum of } \\
4 \text { hours past the point and time in was removed from temperature control } \\
\text { must be marked.* }\end{array}$ & $.06 \pm .25^{\mathrm{w}}$ & $.04 \pm .20^{\mathrm{w}}$ & $.14 \pm .34^{\mathrm{x}}$ & $.05 \pm .23^{\mathrm{w}}$ & 6.67 & .000 \\
\hline \multicolumn{7}{|l|}{ Chemical Handling } \\
\hline $\begin{array}{l}\text { Working containers containing toxic or poisonous chemicals clearly } \\
\text { labeled with the common name.* }\end{array}$ & $.16 \pm .37^{\mathrm{w}}$ & $.05 \pm .22^{\mathrm{x}}$ & $.11 \pm .32^{\mathrm{wx}}$ & $.08 \pm .27^{\mathrm{x}}$ & 5.09 & .002 \\
\hline $\begin{array}{l}\text { Poisonous or toxic materials shall be stored so they cannot contaminate } \\
\text { food, equipment, utensils, linens, and single service and single-use } \\
\text { articles.* }\end{array}$ & $.11 \pm .31^{\mathrm{wx}}$ & $.10 \pm .30^{\mathrm{wx}}$ & $.08 \pm .28^{\mathrm{w}}$ & $.19 \pm .40^{x}$ & 4.97 & .002 \\
\hline $\begin{array}{l}\text { Only poisonous or toxic materials required for the operation and } \\
\text { maintenance of a foodservice shall be allowed in the establishment.* }\end{array}$ & $.02 \pm .15$ & $.01 \pm .08$ & $.01 \pm .09$ & $.00 \pm .00$ & 2.71 & .044 \\
\hline
\end{tabular}


Table 3. Individual Inspection Items with Significant $(p \leq .05)$ differences Based on Type of Restaurant $(n=943)$

\begin{tabular}{|c|c|c|c|c|c|c|}
\hline \multirow[b]{2}{*}{ Description of Violation } & \multicolumn{4}{|c|}{ Mean \pm Standard Deviation } & \multirow[b]{2}{*}{$F$ value $^{\text {a }}$} & \multirow[b]{2}{*}{$P$ value } \\
\hline & $\begin{array}{c}\text { Independen } \\
\text { t Ethnic } \\
\text { Operations } \\
(\mathbf{n}=\mathbf{2 5 0})\end{array}$ & $\begin{array}{c}\text { Chain } \\
\text { Ethnic } \\
\text { Operations } \\
(\mathbf{n}=174)\end{array}$ & $\begin{array}{c}\text { Independen } \\
\text { t Non- } \\
\text { ethnic } \\
\text { Operations } \\
(n=250)\end{array}$ & $\begin{array}{c}\text { Chain } \\
\text { Non-ethnic } \\
\text { Operations } \\
(\mathbf{n}=\mathbf{2 5 0})\end{array}$ & & \\
\hline \multicolumn{7}{|l|}{ Chemical Handling (Continued) } \\
\hline $\begin{array}{l}\text { Poisonous or toxic materials shall be handled according to the law, } \\
\text { manufacturer's directions, certification conditions (if required), and any } \\
\text { additional conditions set forth by the regulatory authority.* }\end{array}$ & $.09 \pm .28^{\mathrm{w}}$ & $.04 \pm .20^{\mathrm{wx}}$ & $.07 \pm .25^{\mathrm{wx}}$ & $.02 \pm .15^{\mathrm{x}}$ & 3.74 & .011 \\
\hline \multicolumn{7}{|l|}{ Conformance with Approved Procedures } \\
\hline $\begin{array}{l}\text { Variance is required before smoking food, curing food, using food } \\
\text { additives, packing foods using reduced oxygen packaging, using a } \\
\text { molluscan shellfish display tank, and sprouting seeds or beans.* }\end{array}$ & $.02 \pm .13$ & $.00 \pm .00$ & $.00 \pm .00$ & $.00 \pm .00$ & 3.64 & .013 \\
\hline $\begin{array}{l}\text { Operations using reduced oxygen packaging with hazardous foods must } \\
\text { ensure at least two barriers are in place to control Clostridium botulinum } \\
\text { and Listeria monocytognes. A HACCP plan must be established and } \\
\text { contain specified information.* }\end{array}$ & $.00 \pm .00$ & $.00 \pm .00$ & $.01 \pm .11$ & $.00 \pm .00$ & 2.72 & .044 \\
\hline \multicolumn{7}{|l|}{ Cooling Methods } \\
\hline $\begin{array}{l}\text { Stored frozen foods shall maintain frozen. Cooling shall be accomplished } \\
\text { in accordance with the time and temperature criteria. }{ }^{*}\end{array}$ & $.08 \pm .27^{\mathrm{w}}$ & $.02 \pm .15^{\mathrm{x}}$ & $.03 \pm .18^{\mathrm{x}}$ & $.00 \pm .06^{\mathrm{x}}$ & 7.64 & .000 \\
\hline \multicolumn{7}{|l|}{ Thawing Methods } \\
\hline $\begin{array}{l}\text { Frozen potentially hazardous foods shall be held at any temperature to keep } \\
\text { food frozen of at } 5 \text { degrees } C \text {. Thawing hazardous foods can be done under } \\
\text { refrigeration, submerged under running water, or as part of a cooking } \\
\text { process. }\end{array}$ & $.14 \pm .34^{\mathrm{w}}$ & $.03 \pm .18^{\mathrm{x}}$ & $.03 \pm .18^{\mathrm{x}}$ & $.01 \pm .09^{\mathrm{x}}$ & 16.37 & .000 \\
\hline \multicolumn{7}{|l|}{ Thermometers Provided \& Accurate } \\
\hline $\begin{array}{l}\text { Food thermometers provided \& accessible; Appropriate thermometer for } \\
\text { measuring thin foods provided. }\end{array}$ & $.08 \pm .28^{\mathrm{w}}$ & $.02 \pm .13^{\mathrm{x}}$ & $.05 \pm .22^{\mathrm{wx}}$ & $.02 \pm .14^{\mathrm{x}}$ & 5.31 & .001 \\
\hline \multicolumn{7}{|c|}{ Insects, Rodents, \& Animals Control; No unauthorized persons } \\
\hline $\begin{array}{l}\text { Openings to outside protected against entry of pest; Protective barriers } \\
\text { provided for exterior walls/roofs.* }\end{array}$ & $.12 \pm .34^{\mathrm{w}}$ & $.10 \pm .31^{\mathrm{wx}}$ & $.07 \pm .26^{\mathrm{wx}}$ & $.05 \pm .21^{\mathrm{x}}$ & 3.16 & .024 \\
\hline \multicolumn{7}{|c|}{ Contamination Prevented During Food Preparation, Storage, \& Display } \\
\hline $\begin{array}{l}\text { Food stored 6" off the floor in clean, dry location \& not stored in } \\
\text { prohibited areas. }\end{array}$ & $.12 \pm .36^{\mathrm{w}}$ & $.04 \pm .20^{\mathrm{x}}$ & $.04 \pm .19^{\mathrm{x}}$ & $.02 \pm .15^{\mathrm{x}}$ & 7.53 & .000 \\
\hline \multicolumn{7}{|l|}{ In-Use Utensils } \\
\hline In-use utensils properly stored between uses. & $.19 \pm .39^{\mathrm{w}}$ & $.12 \pm .33^{\mathrm{wx}}$ & $.10 \pm .30^{\mathrm{x}}$ & $.05 \pm .22^{\mathrm{x}}$ & 8.62 & .000 \\
\hline \multicolumn{7}{|l|}{ Food \& Nonfood-Contact Surfaces } \\
\hline Utensils/food-contact surfaces made of safe, durable, smooth materials. ${ }^{*}$ & $.16 \pm .37^{\mathrm{w}}$ & $.06 \pm .23^{\mathrm{x}}$ & $.02 \pm .14^{\mathrm{x}}$ & $.02 \pm .13^{\mathrm{x}}$ & 20.82 & .000 \\
\hline $\begin{array}{l}\text { Food-contact surfaces smooth \& easily accessible for cleaning; CIP } \\
\text { equipment easily cleanable.* }\end{array}$ & $.09 \pm .28$ & $.05 \pm .21$ & $.06 \pm .23$ & $.11 \pm .32$ & 2.86 & .036 \\
\hline
\end{tabular}


Table 3. Individual Inspection Items with Significant $(p \leq .05)$ differences Based on Type of Restaurant $(n=943)$

\begin{tabular}{|c|c|c|c|c|c|c|}
\hline \multirow[b]{2}{*}{$\begin{array}{r}\text { Description of Violation } \\
\end{array}$} & \multicolumn{4}{|c|}{ Mean \pm Standard Deviation } & \multirow[b]{2}{*}{$F$ value $^{\mathrm{a}}$} & \multirow[b]{2}{*}{$P$ value } \\
\hline & $\begin{array}{l}\text { Independen } \\
\text { t Ethnic } \\
\text { Operations } \\
(\mathbf{n}=\mathbf{2 5 0})\end{array}$ & $\begin{array}{c}\text { Chain } \\
\text { Ethnic } \\
\text { Operations } \\
(\mathbf{n}=174)\end{array}$ & $\begin{array}{l}\text { Independen } \\
\text { t Non- } \\
\text { ethnic } \\
\text { Operations } \\
(n=250) \\
\end{array}$ & $\begin{array}{c}\text { Chain } \\
\text { Non-ethnic } \\
\text { Operations } \\
(\mathbf{n}=\mathbf{2 5 0}) \\
\end{array}$ & & \\
\hline \multicolumn{7}{|l|}{ Warewashing Facilities } \\
\hline $\begin{array}{l}\text { Thermometer for testing sanitizing water temperature } \& / \text { or test kit for } \\
\text { measuring sanitizer concentration provided. }\end{array}$ & $.15 \pm .36^{\mathrm{w}}$ & $.06 \pm .23^{\mathrm{x}}$ & $.11 \pm .32^{\mathrm{wx}}$ & $.05 \pm .21^{\mathrm{x}}$ & 6.238 & .000 \\
\hline Warewashing sinks cleaned \& sanitized after used for different purposes. & $.02 \pm .13$ & $.01 \pm .08$ & $.00 \pm .00$ & $.00 \pm .00$ & 2.655 & .047 \\
\hline Equipment maintained free of encrusted grease/soil deposits.* & $.16 \pm .37^{\mathrm{w}}$ & $.06 \pm .23^{\mathrm{x}}$ & $.10 \pm .30^{\mathrm{wx}}$ & $.06 \pm .24^{\mathrm{x}}$ & 6.632 & .000 \\
\hline $\begin{array}{l}\text { Nonfood-contact surfaces cleaned at frequency to prevent buildup of } \\
\text { residue. }\end{array}$ & $.16 \pm .37^{\mathrm{w}}$ & $.05 \pm .21^{\mathrm{x}}$ & $.06 \pm .25^{\mathrm{x}}$ & $.06 \pm .23^{\mathrm{x}}$ & 9.386 & .000 \\
\hline \multicolumn{7}{|l|}{ Hot \& Cold Water Availability } \\
\hline Capacity \& pressure of potable water adequate to meet facility demands. ${ }^{*}$ & $.03 \pm .18^{\mathrm{w}}$ & $.01 \pm .11^{\mathrm{wx}}$ & $.00 \pm .00^{x}$ & $.01 \pm .11^{\mathrm{wx}}$ & 3.193 & .023 \\
\hline $\begin{array}{l}\text { Water reservoir of fogging devices maintained \& cleaned; Plumbing } \\
\text { system maintained in good repair.* }\end{array}$ & $.18 \pm .38^{\mathrm{w}}$ & $.11 \pm .32^{\mathrm{wx}}$ & $.06 \pm .24^{\mathrm{x}}$ & $.12 \pm .33^{\mathrm{wx}}$ & 5.816 & .001 \\
\hline \multicolumn{7}{|l|}{ Adequate Ventilation \& Lighting } \\
\hline Protective shielding on light bulbs over exposed food/utensils/equipment. & $.04 \pm .21^{\mathrm{w}}$ & $.00 \pm .00^{\mathrm{x}}$ & $.02 \pm .13^{\mathrm{wx}}$ & $.01 \pm .11^{\mathrm{wx}}$ & 4.109 & .007 \\
\hline $\begin{array}{l}\text { Ventilation system cleaned in way not to cause contamination or create a } \\
\text { public health hazard. }\end{array}$ & $.04 \pm .21$ & $.00 \pm .00$ & $.02 \pm .15$ & $.01 \pm .09$ & 2.836 & .037 \\
\hline Designated dressing rooms/lockers used by employees. & $.02 \pm .14^{\mathrm{W}}$ & $.00 \pm .00^{\mathrm{wx}}$ & $.00 \pm .00^{\mathrm{x}}$ & $.00 \pm .00^{\mathrm{x}}$ & 4.565 & .004 \\
\hline \multicolumn{7}{|l|}{ Sanitary Operations } \\
\hline $\begin{array}{l}\text { Physical facilities maintained in good repair \& cleaned as often as } \\
\text { necessary to keep them clean. }\end{array}$ & $.23 \pm .48^{\mathrm{w}}$ & $.10 \pm .37^{\mathrm{x}}$ & $.11 \pm .38^{\mathrm{x}}$ & $.12 \pm .36^{\mathrm{x}}$ & 5.290 & .001 \\
\hline $\begin{array}{l}\text { A licensee shall immediately discontinue operations and notify the } \\
\text { regulatory authority if an imminent health hazard exists. }\end{array}$ & $.04 \pm .19^{\mathrm{w}}$ & $.01 \pm .11^{\mathrm{wx}}$ & $.02 \pm .15^{\mathrm{wx}}$ & $.00 \pm .00^{\mathrm{x}}$ & 3.311 & .020 \\
\hline
\end{tabular}

regulatory authority if an imminent health hazard exists.

Note: Means with different superscripts (w, $\mathrm{x}$, y series) differed significantly by Scheffe's post hoc test, $P<0.05$

${ }^{a}$ Results from Analysis of Variance (ANOVA)

*Denotes that the item is considered a critical violation per Kansas Food Code 